\title{
Comparative relative toxicity of some modern insecticides against Spodoptera litura fabricius on groundnut
}

\author{
NAVEEN KUMAR NUKALA* AND M.F. ACHARYA \\ Departmment of Entomology, Junagadh Agricultural University, JUNAGADH, (GUJARAT) INDIA
}

\section{ARITCLE INFO \\ Received : 29.01 .2015 \\ Revised : 27.02 .2015 \\ Accepted : 13.03 .2015}

\section{KEY WORDS :}

Comparative relative toxicity,

Spodoptera litura, Groundnut

*Corresponding author:

Email: nukalanaveen4u@gmail.com

\begin{abstract}
Investigation on comparative relative toxicity of some modern insecticides against $S$. litura revealed that emamectin benzoate was the most toxic and effective insecticide as its $\mathrm{LC}_{50}$ value was 0.000954 . Notably, emamectin benzoate proved very effective in laboratory, as evident from its low $\mathrm{LC}_{50}$ values against $S$. litura. As emamectin benzoate is a novel semi-synthetic derivative of the natural product was found to be most toxic. On the other hand, spinosad found to be the least toxic in which the $\mathrm{LC}_{50}$ value was worked out to the tune of 0.0158 .
\end{abstract}

How to view point the article : Nukala, Naveen Kumar and Acharya, M.F. (2015). Comparative relative toxicity of some modern insecticides against Spodoptera litura fabricius on groundnut. Internat. J. Plant Protec., 8(1) : 148-151. 